\title{
USE OF TACROLIMUS IN RESCUE THERAPY OF ACUTE AND CHRONIC REJECTION IN LIVER TRANSPLANTATION
}

\author{
Fabricio Ferreira Coelho, Rafael Ferreira Coelho, Paulo Celso Bosco Massarollo \\ and Sérgio Mies
}

COELHO FF et al. - Use of tacrolimus in rescue therapy of acute and chronic rejection in liver transplantation. Rev. Hosp.

Clín. Fac. Med. S. Paulo 58(3):141-146, 2003.

PURPOSE: To study the indications and results of tacrolimus as rescue therapy for acute cellular or chronic rejection in liver transplantation.

PATIENTS AND METHODS: Eighteen liver transplant recipients who underwent rescue therapy with tacrolimus between March 1995 and August 1999 were retrospectively studied. The treatment indication, patients, and graft situation were recorded as of October $31^{\text {st }}$, 1999. The response to tacrolimus was defined as patient survival with a functional graft and histological reversal of acute cellular, or for chronic rejection, bilirubin serum levels decreasing to up to twice the upper normal limit.

RESULTS: Fourteen cases $(77.8 \%)$ presented a good response. The response rate for the different indications was: (1) acute cellular + sepsis - 0/1 case; (2) recurrent acute cellular - 1/1 case; (3) OKT3-resistant acute cellular - 2/2 cases; (4) steroid-resistant acute cellular + active viral infection - 3/3 cases; (5) chronic rejection - 8/11 cases (72.7\% response rate). The 4 patients who did not respond died.

CONCLUSION: Tacrolimus rescue therapy was successful in most cases of acute cellular and chronic rejection in liver transplantation.

DESCRIPTORS: Liver transplantation. Adverse effects. Immunosuppression. Tacrolimus. Therapeutic use.

After the advent of cyclosporin in 1980, the survival rate of patients undergoing liver transplantation (LTx) improved dramatically ${ }^{1}$. At our unit, cyclosporin in combination with azathioprine and corticosteroids constitutes the drug of choice for immunosuppressive therapy in LTx. With this therapeutic regimen, about $30 \%$ of the patients undergoing LTx presented episodes of acute cellular rejection (ACR) ${ }^{2}$. Recent studies have shown that up to $13 \%$ of the episodes of ACR are refractory to the standard treatment with corticosteroids $^{3}$. For this reason, ACR continues to be a cause of graft loss ${ }^{4-6}$.

The most widely used agent in the treatment of steroid-resistant ACR is
OKT3, a monoclonal antibody that blocks lymphocyte-mediated cytotoxicity by binding with the CD3 receptor $^{7}$. However, its use is limited by adverse reactions, by an increased occurrence of opportunistic infectious diseases, and by lymphoproliferative disorders, as well as the high $\operatorname{cost}^{8,9}$.

More recently, tacrolimus (FK506) made its appearance as an alternative immunosuppressive drug. It became

From the Department of Surgery, Faculty of Medicine, University of São Paulo, São Paulo/SP, Brazil.

Received for publication on August 19, 2002. available in Europe in $1990 .^{10}$ FK506 is a macrolide compound isolated from Streptomyces tsukubaensis and has an immunosuppressive potential approximately 100 times more powerful than cyclosporin ${ }^{11,12}$. The drug acts by binding to cytoplasmic proteins of the lymphocytes, primarily FKBP12, forming a complex that associates with calcineurin. Some direct or indirect substrates of calcineurin act as transcription factors and promote the activation of genes that encode cytokine production.

This activation is dependent on the calcium influx into the cell. The association of calcineurin to the FK506 complex prevents stimulatory signal 
transduction, inhibiting the formation of interleukin-2 by the T-lymphocytes and the formation of other soluble mediators, such as interleukin-3 and interferon- $\gamma^{11,12}$.

The introduction of FK506 has added an alternative to OKT3 for rescue therapy of steroid-resistant ACR. It also has opened new possibilities for the pharmacological control of chronic liver graft rejection (CR), which until that time, was treated exclusively by retransplantation $^{13}$.

The purpose of this study was to analyze the indication criteria and the results of employing FK506 in rescue therapy of acute and chronic rejection in LTx.

\section{PATIENTS AND METHODS}

All 244 LTx performed at our unit between March 1995 and August 1999 were retrospectively studied. Among these, we identified and analyzed 7 cases of ACR and 11 cases of CR that had been converted to FK506 for rescue therapy.

Eight of the 18 patients who underwent rescue therapy with FK506 were males. The mean age was $39.1 \pm 15.4$ years (16 to 64 years). The indications for LTx for these patients are shown in table 1 .

Table 1 - Indications for liver transplantation in patients undergoing rescue therapy with tacrolimus for acute and chronic rejections.

Indications n

primary sclerosing cholangitis

hepatitis $\mathrm{C}$ cirrhosis

acute liver failure

ductopenic disease

primary biliary cirrhosis

alcoholic cirrhosis

cryptogenic cirrhosis

familial amyloidotic polyneuropathy

hemochromatosis

$\alpha 1$-antitrypsin deficiency

autoimmune hepatitis
The primary immunosuppressive therapy for all patients was based on cyclosporin, prednisone, and azathioprine, according to the standard service protocol. According to this regimen, $1 \mathrm{~g}$ of methylprednisolone was delivered intravenously at the time of revascularization, and $200 \mathrm{mg}$ of prednisone or methylprednisolone were delivered on the immediate postoperative day (PO). This dosage was tapered to $40 \mathrm{mg}$ /day until the maintenance dosage of $20 \mathrm{mg} /$ day was achieved on the sixth PO. Azathioprine was administered orally, at a daily dosage of 1 $\mathrm{mg} / \mathrm{kg}$. Cyclosporin was introduced orally between the first and third PO, $10 \mathrm{mg} / \mathrm{kg}$, divided into 2 daily doses. The dosage was adjusted daily to achieve a target trough blood level between 300 and $350 \mathrm{ng} / \mathrm{mL}$ (monoclonal TDX). During the first year PO, the dosage of cyclosporin was progressively reduced to attain a trough blood level of approximately $100 \mathrm{ng} / \mathrm{mL}$. During the same period, the dosage of prednisone was reduced to $5 \mathrm{mg} /$ day. ACR episodes were treated with 1 to 3 pulses of $1 \mathrm{~g}$ of methylprednisolone, followed by a 6 day taper from 200 to $20 \mathrm{mg} /$ day.

Rescue therapy with FK506 was individualized in each case. Only the oral formulation of FK506 was used. The initial dosage ranged from 0.1 to $0.3 \mathrm{mg} / \mathrm{kg} / \mathrm{day}$, and was adjusted according to the trough blood level. Initially the target blood level was maintained around $15 \mathrm{ng} / \mathrm{mL}$. However, the target level was set on an individual basis according to the patient's clinical response and the severity of the side effects. One month after conversion, the mean dosage of FK506 was $0.2 \pm 0.1 \mathrm{mg} / \mathrm{kg} /$ day. During this period, the mean blood level was $13.8 \pm$ $5.9 \mathrm{ng} / \mathrm{mL}$. Corticosteroid administration was maintained in all cases. Five patients received combination therapy with mycophenolate mofetil (MMF) in dosages ranging from 1.0 to $3.0 \mathrm{~g} /$ day.

The diagnosis of ACR and CR was suspected because of clinical and laboratory alterations. All ACR episodes

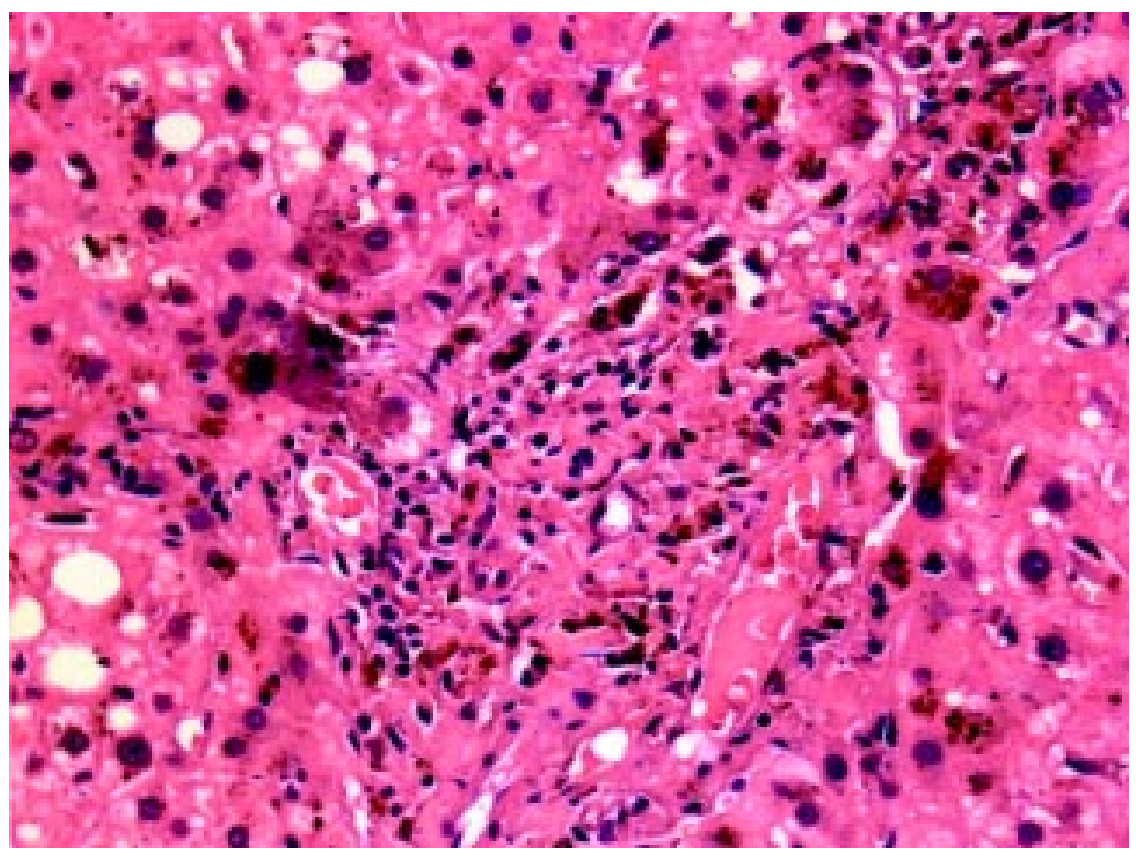

Figure 1 - Liver biopsy showing the loss of small bile ducts in the portal tract. Note the deposition of hemosiderin in hepatocytes and macrophages. 
were histologically confirmed. The 11 diagnoses of CR were established using one of the following three criteria: 1 - characterization of ductopenia in liver biopsy ${ }^{14}$, in 5 patients (Fig. 1); 2presence of bile duct damage in the biopsy, ${ }^{14}$ with normal cholangiography and hepatic angiography, in 5 cases (Fig. 2); 3- presence of duct aggression with angiographic demonstration of

multiple intrahepatic arterial strictures in 1 case (Fig. 3).

Steroid-resistant ACR was defined as the persistence of the clinical, biochemical, and histopathological signs of rejection after treatment with at least 2 pulses of $1.0 \mathrm{~g}$ of methylprednisolone. OKT3-resistant ACR was defined as the persistence of the clinical, biochemical, and histopathological

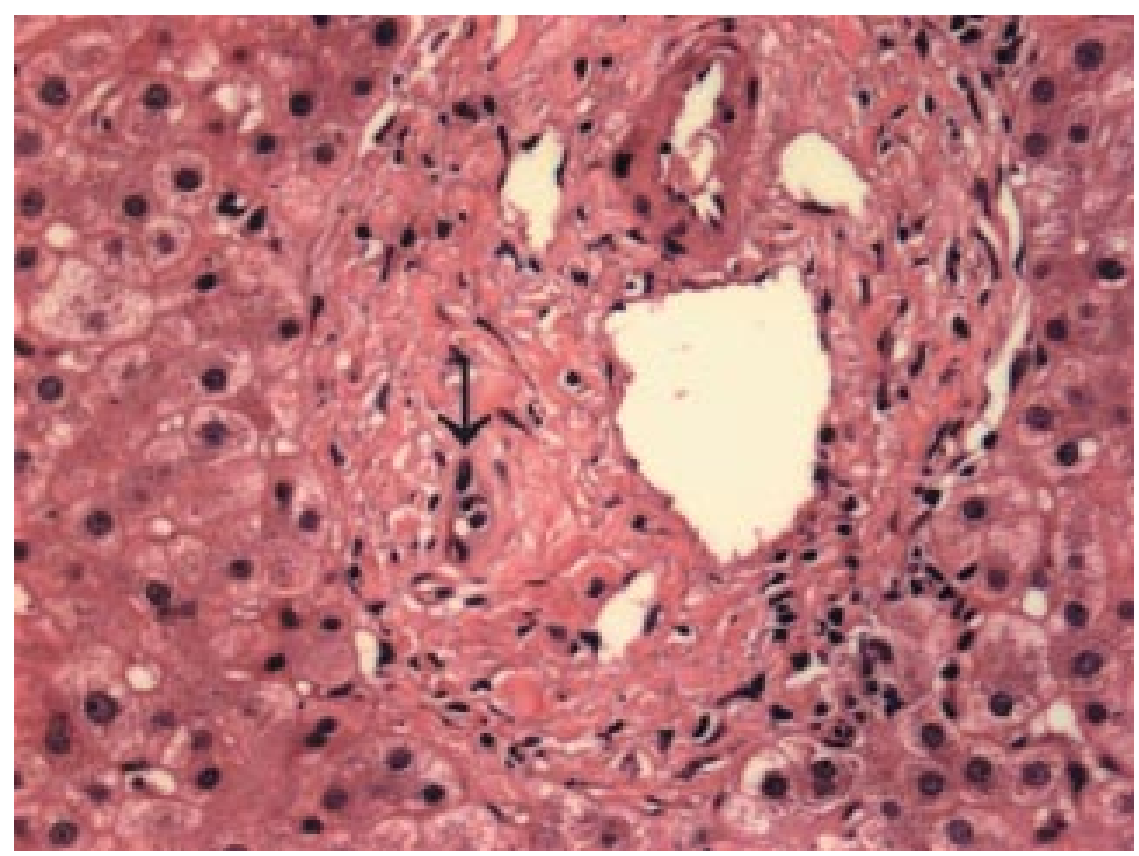

Figure 2 - Liver biopsy showing degenerative alterations in the interlobular bile ducts (arrow). Note the cytoplasmic eosinophilia, the nuclear pyknosis, and the absence of portal inflammation.

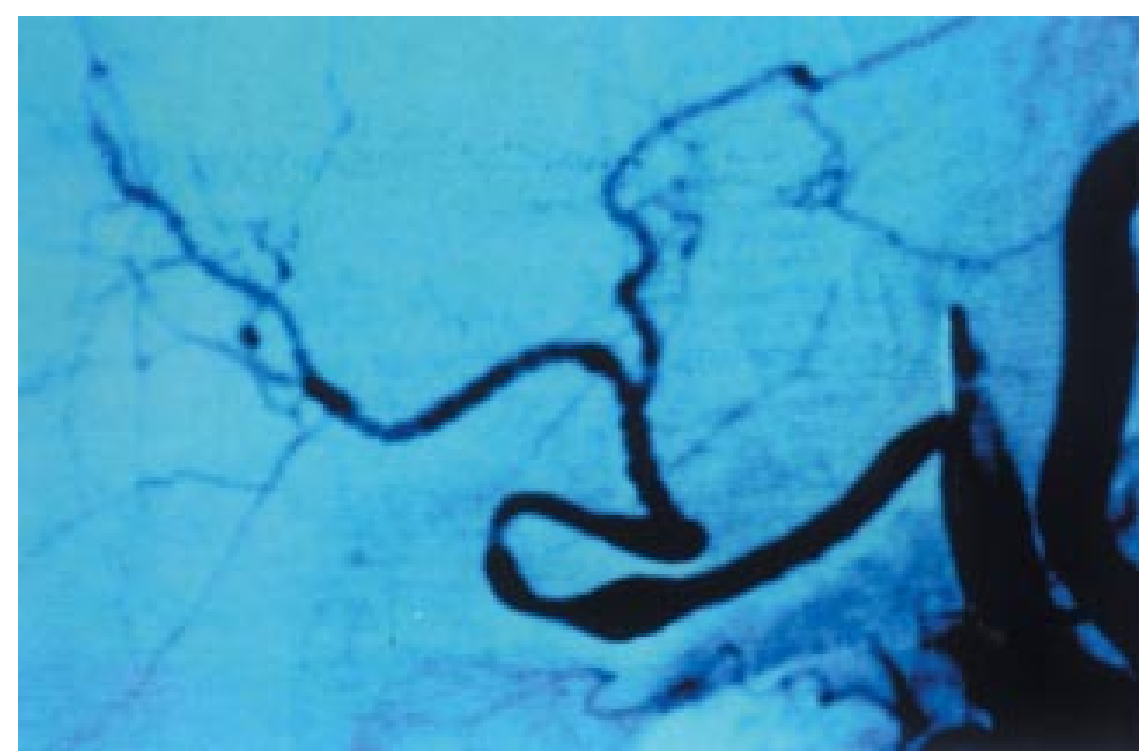

Figure 3 - Angiographic study of the liver graft showing multiple arterial strictures. signs of rejection after treatment with the drug for at least 10 days.

In the 18 cases studied, the following data were recorded: date of LTx, indication for rescue therapy, date of conversion, follow-up period, and patient and graft situation on October $31^{\text {st }}, 1999$.

The response to FK506 was defined as patient survival with functional graft and histological reversal of ACR, or for CR, bilirubin serum levels decreasing to up to twice the upper normal limit.

The patients' actuarial survival rates were calculated using the KaplanMeier method.

\section{RESULTS}

Five different indications for rescue therapy with FK506T were identified: 1) ACR plus bacterial sepsis $(n=1) ; 2)$ recurrent ACR (n=1); 3) OKT3-resistant $\operatorname{ACR}(\mathrm{n}=2) ; 4)$ steroid-resistant ACR plus active viral disease $(n=3) ; 5$ ) chronic rejection $(\mathrm{n}=11)$.

The patient with recurrent ACR presented 4 rejection episodes in a 4month period. Among the 3 patients with ACR plus active viral disease, 2 presented cytomegalovirus (CMV) hepatitis, and 1 had herpetic gastroenterocolitis.

Table 2 shows the response rate to FK506 for each indication. Fourteen patients $(77.8 \%)$ were considered "patients who responded". All 4 patients with no response died. The mean follow-up time after conversion to FK506 was 19.8 months, ranging from 10 days to 48 months.

The 47-month actuarial survival rates were up to $61.5 \%$ in cases of $\mathrm{CR}$ (Fig. 4). Figures 5, 6, and 7 show the evolution of the serum levels of total bilirubin, alkaline phosphatase, and alanine transaminase (ALT) during the first 12 months of treatment with FK506. 
Table 2 - Results: indication for conversion to tacrolimus, percentage of response and mean follow-up.

\begin{tabular}{lccc}
\hline Indication for conversion to tacrolimus & $\mathrm{n}$ & Response & $\begin{array}{c}\text { Mean follow up } \\
\text { (months) }\end{array}$ \\
\hline ACR + bacterial sepsis & 1 & 0 & 0.3 \\
Recurrent ACR & 1 & 1 & 2.0 \\
OKT3-resistant ACR & 2 & 2 & $43.5(39-48)$ \\
Steroid-resistant ACR + viral infection & 3 & 3 & $39.3(31-46)$ \\
Chronic rejection & 11 & $8(72.7 \%)$ & $13.5(0.5-47)$ \\
Total & 18 & $14(77.8 \%)$ & $19.8(0.3-48)$ \\
\hline
\end{tabular}

$\mathrm{ACR}=$ acute cellular rejection.

\section{DISCUSSION}

Several clinical studies have evaluated the effects of FK506 on rescue therapy of CR or ACR in LTx recipients ${ }^{15}$. Most have demonstrated the beneficial effects of the drug, with a success rate of up to $89 \%$ for steroidresistant $\mathrm{ACR}^{16}$.

Sher et al. ${ }^{17}$ obtained a response rate of $70.3 \%$ in patients with CR, while Platz et al. ${ }^{16}$ reported a success rate of $88.9 \%$ in patients with steroidresistant ACR. In the present study, the response rate was $72.7 \%$ and $85.7 \%$ in cases of CR and ACR, respectively.

In the present study, the survival rate of the patients undergoing rescue therapy for CR was $61.5 \%$ at 2 years (Fig. 4). Sher et al. ${ }^{17}$ observed an $81.2 \%$ survival rate with the same follow-up, while Jonas et al. ${ }^{5}$ obtained a $76 \%$ survival rate.

In the present study, only 3 patients $(16.7 \%)$ were less than 18 years old; the youngest patient was 16 . Thus, our results refer basically to an adult population. Other authors, however, have shown positive long-term results with FK506 rescue therapy for pediatric patients. Reyes et al. ${ }^{18}$, studying pediatric LTx recipients, obtained a patient survival rate of $78.1 \%$

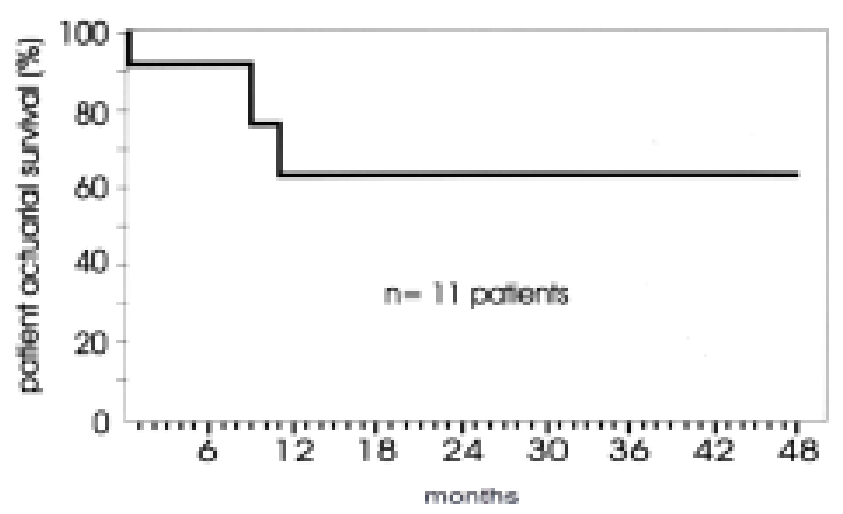

Figure 4 - Actuarial survival of the 11 patients with chronic rejection of the liver graft undergoing rescue therapy with tacrolimus.

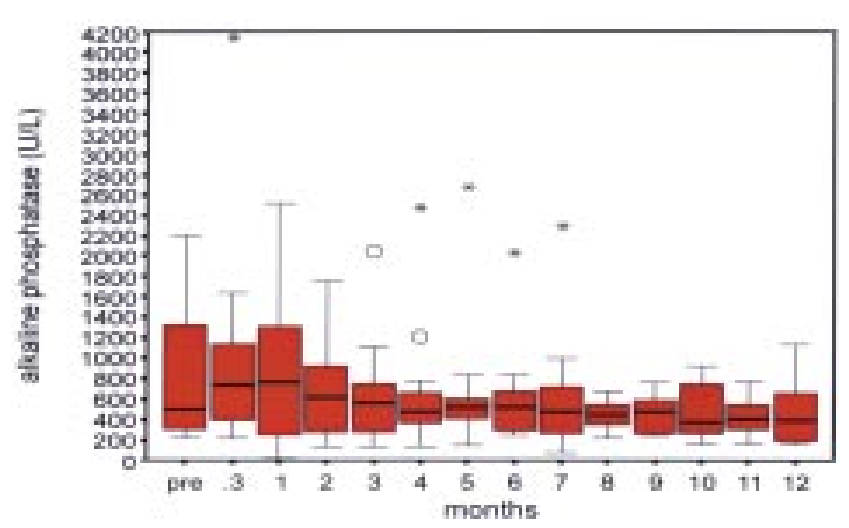

Figure 6 - Evolution of alkaline phosphatase serum levels in patients undergoing rescue therapy with tacrolimus for treatment of chronic rejection of the liver graft. The upper normal limit of alkaline phosphatase is $223 \mathrm{U} / \mathrm{L}$.

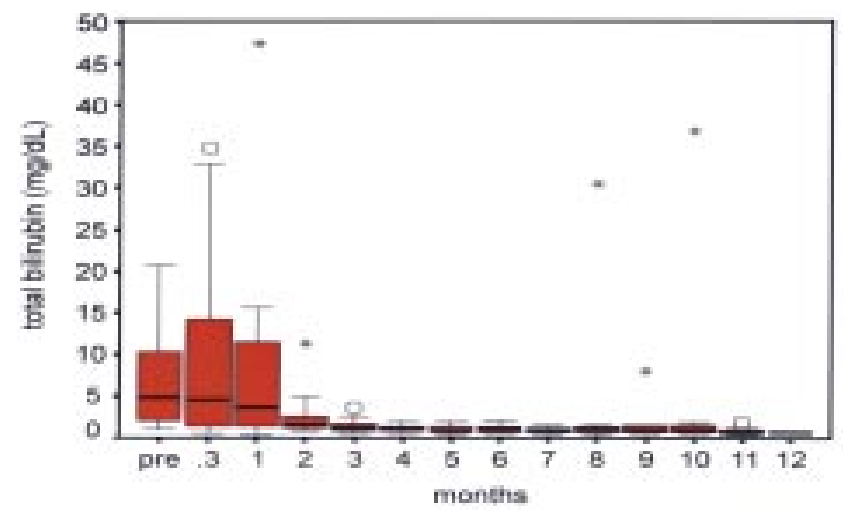

Figure 5 - Evolution of total bilirubin serum levels in patients undergoing rescue therapy with tacrolimus for the treatment of chronic rejection of the liver graft. The upper normal limit of total bilirubin is $1.3 \mathrm{mg} / \mathrm{dL}$.

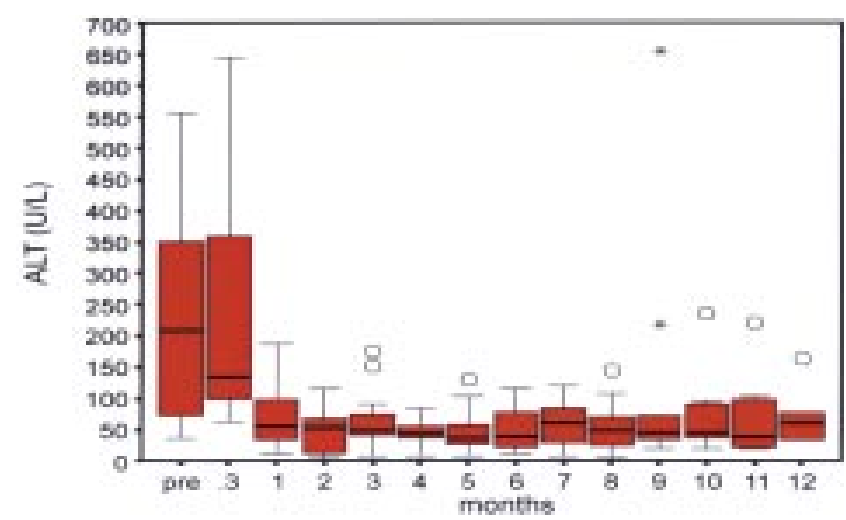

Figure 7 - Evolution of alanine aminotransferase serum levels in patients undergoing rescue therapy with tacrolimus for treatment of chronic rejection of the liver graft. The upper normal limit of alanine aminotransferase is $32 \mathrm{U} / \mathrm{L}$. 
and $74.6 \%$ at the 5- and 8-year followup, respectively. In the cases converted due to ACR $(95.5 \%$ survival at 8 years), results were better than for cases of CR (74.6\%).

Considering the positive efficacy of FK506, some authors propose it as the drug of choice for steroid-resistant ACR to avoid the use of anti-lymphocyte antibodies $^{11,12}$. Some studies have shown that the need for retransplantation is more marked in patients undergoing OKT3 rescue therapy (15.8\%) than in patients treated with FK506 $(5.5 \%)^{16}$. Thus, the indication for OKT3 for steroid-resistant ACR has been restricted, and its use has declined in several transplant centers ${ }^{16}$.

There are some prognostic factors related to the therapeutic success rate of FK506 $6^{5,17}$. Jonas et al..$^{5}$, studying patients with ACR, found a significant lower bilirubin level prior to the conversion in patients who responded (12.0 $\pm 5.6 \mathrm{mg} \%$ vs. $29.7 \pm 5.9 \mathrm{mg} \% ; P<$ $0.05)$. Sher et al. ${ }^{17}$ identified 2 independent prognostic factors in patients with CR: total bilirubin and the time elapsed between LTx and conversion. The cases of total bilirubin greater than $10 \mathrm{mg} / \mathrm{dL}$ presented a $13.8 \%$ 2-year graft survival, compared to $86.0 \%$ for patients with a level below this value. Patients converted up to 90 days after LTx had a graft survival of $51.9 \%$ compared to $87.7 \%$ for patients converted later. In the present study, the bilirubin level was correlated with a similar effect in patients with CR. Two of the 3 patients who died presented a total pre- conversion bilirubin level higher than $10 \mathrm{mg} / \mathrm{dL}$. Inversely, only 2 of the 8 patients who responded presented a bilirubin level above this value. The median time elapsed between LTx and the beginning of the rescue therapy was 127 days for patients who did not respond (range 64 to 536 days), and 146 days for patients treated successfully (range 27 to 836 days).

Similarly to other studies ${ }^{17,18}$, the criteria used to determine a positive response in CR were based only on clinical and biochemical data. It would, however, be interesting to clarify the effect of the conversion to FK506 on the histological and angiographic alterations found initially. Unfortunately this information was not available, since the patients who responded did not undergo control biopsies or angiographies. Perhaps the question can be clarified in a prospective study about rescue therapy of CR.

Regarding the biochemical evolution, Sher et al. ${ }^{17}$ described a significant drop in mean bilirubin levels in the group of patients who responded, from $7.1 \mathrm{mg} / \mathrm{dL}$ prior to conversion to $3.4 \mathrm{mg} / \mathrm{dL}$ after 2 years. In patients who did not respond the mean bilirubin level was $19.8 \mathrm{mg} / \mathrm{dL}$ at the time of conversion, and remained 14.0 $\mathrm{mg} / \mathrm{dL}$ at the time of retransplantation ${ }^{17}$. Similarly, ALT was also indicated as a prognostic factor, presenting a significantly larger reduction in patients who responded ${ }^{17}$. In the present study, mean total bilirubin and ALT levels dropped progressively during treatment with FK506 (Figs. 5 and 7). A similar profile was observed with alkaline phosphatase levels (Fig. 6). Despite the biochemical response, the median values of these enzymes were approximately twice the upper normal limit 12 months after conversion.

MMF was combined with FK506 in 5 patients because of different reasons and at variable periods. In 2 cases of CR, MMF was given due to FK506 nephrotoxicity. The first patient began MMF therapy 1 month after conversion, and the dosage of FK506 was reduced. An improvement of renal function was observed, while rejection persisted but was controlled. In the second case, MMF and cyclosporine were given 11 months after conversion, and FK506 was withdrawn. The patient presented a recovery of renal function without rejection relapse. In 2 other patients with CR, MMF was initiated 15 and 18 days after conversion due to a poor biochemical response. In the first, a rapid biochemical improvement was observed, while the slow decline in bilirubin and enzyme levels persisted in the second. In time, both cases were considered patients who responded. For the fifth patient who underwent rescue therapy because of an OKT3-resistant ACR, FK506 plus MMF were introduced simultaneously for a more powerful immunosuppressive regimen.

We conclude that FK506 is effective in rescue therapy of most cases of acute and chronic rejection in liver transplantation.

\section{RESUMO}

COELHO FF e col. - Uso de tacrolimus na terapia de resgate de rejeições agudas e crônicas no transplante de fígado. Rev. Hosp. Clín. Fac. Med. S. Paulo 58 (3):141-146, 2003.
OBJETIVO: Estudar os critérios de indicação e o resultado do uso de tacrolimus na terapia de resgate de rejeições agudas ou crônicas no transplante de fígado.
CASUÍSTICA E MÉTODO: Foram estudados 18 pacientes transplantados de fígado, submetidos a terapia de resgate com tacrolimus entre março de 1995 e agosto de 1999. Foram 
registradas a indicação do tratamento e a situação de pacientes e enxertos em 31/10/1999. Considerou-se "respondendores" pacientes vivos, com enxerto funcionante e regressão histológica da terapia de resgate de rejeições agudas, ou com bilirrubina até 2 vezes o valor normal, no caso de terapia de resgate de rejeições crônicas.

RESULTADO: Observou-se resposta em 14 casos $(77,8 \%)$. A taxa de resposta nas diferentes indicações foi: (1) terapia de resgate de rejeições agudas + sepse bacteriana - 0/1 caso; (2) terapia de resgate de rejeições agudas recorrente - 1/1 caso; (3) terapia de resgate de rejeições agudas resistente a OKT3 - 2/2 casos; (4) terapia de resgate de rejeições agudas resistente a corticóide + doença viral ativa - 3/3 casos; (5) terapia de resgate de rejeições crônicas - 8/11 casos $(72,7 \%$ de resposta). Os quatro casos sem resposta $(22,2 \%)$ evoluíram para óbito.

CONCLUSÃO: O tacrolimus é eficaz na terapia de resgate da maioria dos casos de rejeição celular aguda e crônica no transplante de fígado.

DESCRITORES: Transplante de fígado. Efeitos adversos. Imunossupressão. Tacrolimus. Uso terapêutico.

\section{REFERENCES}

1. SCHARSCHMIDT BF - Human liver transplantation: analysis of data on 540 patients from four centers. Hepatology 1984; 4(Suppl.):95S-101S.

2. MIES S, MASSAROLLO PCB, FIGUEIRA ERR et al. - Lower incidence of liver graft rejection in patients on diltiazem plus cyclosporine therapy. Transplant Proc 1998; 30:1437-1438.

3. TAIBI A, ADHAM M, DUCERF C et al. - Rescue FK506 therapy for acute rejection and early chronic rejection after liver transplantation: report of 14 cases. Transplant Proc 1998; 30:1411-1412.

4. JONAS S, BECHESTEIN WO, TULLIUS SG et al. - Indications for tacrolimus anti-rejection therapy in liver allograft recipients. Transplant Int 1996; 9 (suppl 1):S 164-170.

5. JONAS S, BECHSTEIN WO, LEMMENS HP et al. - Conversion to tacrolimus after liver transplantation. Transplant Int 1996; 9:23-31.

6. HUNG CM, JENG LB, YEH CN et al. - Tacrolimus to rescue refractory hepatic allograft rejection: a collaborative study in Taiwan. Transplant Proc 1998; 30:3589.

7. SAMUEL D, GUGEHEIM J, CANON C, SALIBA F et al. - Use of OKT3 for late acute rejection in liver transplantation. Transplant Proc 1990; 22: 1767-1768.

8. THISTLETHWAITE RJ, STUART JK, MAYES JT et al. Monitoring and complications of monoclonal therapy: complications and monitoring of OKT3 therapy. Am J Kidney Dis 1998; 11: 112-119.

9. SINGH N, DUMMER JS, KUSNE S et al. - Infection with cytomegalovirus and others herpes virus in 121 liver transplant recipients: transmission by donated organs and the effect of OKT3 antibodies. J Infect Dis 1988; 158: 124-131.
10. PRATSCHKE J, NEUHAUS R, TULIUS SG et al. - Treatment of cyclosporine-related adverse effects by conversion to tacrolimus after liver transplantation: long-term results. Transplant Proc 1998; 30:1419-1421.

11. KLINTMALM GB - Clinical use of FK506 in liver transplantation. Transplant Proc 1996; 28: 974-976.

12. SPENCER CM, GOA KL, GILLIS JC - Tacrolimus. An update of its pharmacology and clinical efficacy in the management of organ transplantation. Drugs 1997; 54: 925-975.

13. HUBSCHER S, NEUBERGER J - Chronic rejection of the liver allograft. In: NEUBERGER J, ADAMS D - Immunology of liver transplantation. London, Edward Arnold, 1993. p.216229.

14. DEMETRIS AJ - Spectrum of hepatic allograft rejection and arteriopathy and the controversy of centrilobular necrosis. Liver transplantation 2000; 6:102-103.

15. PLOSKER GL, FOSTER RH - Tacrolimus- A further update of its pharmacological and therapeutic use in the management of organ transplantation. Drugs 2000; 59: 323-389.

16. PLATZ KP, MUELLER AR, ZYTOWSKY M - Management of acute steroid-resistant rejection after liver transplantation. World J Surg 1996; 20:1052-1059.

17. SHER LS, COSENZA CA, MICHEL J et al. - Efficacy of tacrolimus as rescue therapy for chronic rejection in orthotopic liver transplantation: a report of the U. S. Multicenter Liver Study Group. Transplantation 1997; 64:258-263.

18. REYES J, JAIN A, MAZARIEGOS G et al. - Long-term results after conversion from cyclosporine to tacrolimus in pediatric liver transplantation for acute and chronic rejection. Transplantation 2000; 69 (12): 2573-2580. 